UDC 821.133.1.81’42/161.1

\author{
T. N. ZHUZHGINA-ALLAHVERDIAN ${ }^{1 *}$, S. A. OSTAPENKO²* \\ ${ }^{1 *}$ Horlivka Institute of Foreign Languages of the State Higher Educational Institution "Donbas State Pedagogical University" \\ (Bakhmut, Ukraine), e-mail allakverdian.tamara@rambler.ru, ORCID 0000-0002-5953-4424 \\ ${ }^{2 *}$ Donetsk National University of Economics and Trade named after Mykhailo Tugan-Baranovsky (Kryvyi Rih, Ukraine), e-mail \\ ostapenko@donnuet.edu.ua, ORCID 0000-0002-3915-4854
}

\title{
ROMANTIC HUMAN STUDY: PECULIARITIES OF PERSONALITY PHILOSOPHY IN THE LITERATURE OF THE 1820-1830-IES.
}

Purpose. The purpose of the study is to show the connection of romanticism with the anthropological doctrine that goes back to Hegelianism and Kantianism, and at the same time - with the concepts of the future, structuralism and postmodernism. Theoretical basis. The man is a central figure of the Romantic literary, therefore it makes sense to single out romantic human anthropological doctrine and the image of man associated with a specific historical and cultural era called the "epoch of romanticism"; to show that many romantic philosophical positions remained relevant to the basic foundations of contemporary anthropological research and coincide with it in analytical and critical thinking about a man, a person, his historical and evolutionary fate. Originality. The romantic worldview determined the specifics of anthropological discourse, both logical and illogical, remaining symbols and attaching, as for example, a real historical anecdote, a popular history, a philosophical thought, a myth, a famous literary episode and the arts multiplied by creative inspiration and imagination. This tendency determined the fragmentation of thinking and the scientific image of man as a dual being, nevertheless, presented and described in all the variety of relations with the world and with himself, that allows us to call this area of thought "the romantic human science". Conclusions. Structural analysis of numerous romantic texts allows us to draw the following conclusion: with mythopoetic imagery and anthropological thought about a man, romantic writers introduced the reader to any wisdom, to philosophical understanding of their human essence, to past and modern teachings, in a way processed antique, medieval and enlightening views, in which an important place was given to reflections on the place of man in nature, society, and history. Correlating the well-known statements about a person as a descendant of the "old Adam", "person", "personality", "soul", with the modern idea of historical and social development, about the evolution of the consciousness of a person who revealed himself as an individual in modern times, with scientific and aesthetic views, the writers of the first half of the XIX century gave romantic thought anthropological meaning and, in fact, laid the foundations of historical, social, psychological, cultural and psychoanalytic anthropology.

Keywords: romanticism; human being; human study; personality philosophy; philosophy of the "alter"; personal motives; individualism; author's myth; binarity; simulacrum

\section{Introduction}

The problem of a human (Greek ö $v \theta \rho \omega \pi \mathrm{o} \varsigma$ ) is central in romanticism; therefore, it makes sense to single out romantic human study in anthropological science as a separate milestone in the doctrine of a human of a particular historical and cultural period, which was called in scientific literature the "era of romanticism". Romantics study and describe human nature, taking into account the centuries-old experience of cultures and their own observations. They correlate wellknown statements about the "person" with his contemporary scientific understanding of society and individuality, with new ethical and aesthetic views, and at the same time lay the foundations of modern "social science", sociology and psychology, as well as historical, cultural-social, psychological, psycho-cultural anthropology and linguoanthropology.

Romantic authors studied and rethought the accumulated over the centuries' knowledge about nature and human essence, about the unity of a body, soul and spirit, criticizing educating views on the social role of man, his place in the universe, society, and history. Built on contrasts and woven from paradoxes, the romantic idea of the universe and its laws was transferred to the indi- 
vidual personality and his activity, understood "in a higher signification, which is purely psychological and metaphysical" (Schlegel, 1983, p. 380). However, contrary to claims of a "radical break" with the cultural tradition of the 18th century (Shervashidze, 2016, p. 366), romanticism was closely associated with it, in particular, with the teachings of the enlighteners about the contradictoriness of man, which he perceived and embodied in artistic images of the "disease of the century", doubles, shadows; supplemented and developed in the analysis of the psychophysical capabilities of the reflecting personality. Here it is appropriate to use the term by J. Deleuze des liens de transversalité - intersecting ties (Charchare, 2017, p. 7), as well as in relation to the "Confession" by J. J. Rousseau, who was defaced by his contemporaries, but heard by romantics. And the text of the "Dialogues" contained an unheard voice intended for absolute hearing (Foucault, 2015, p. 10). Romantics possessed that perfect sense of pitch, which is necessary to hear not only their close predecessors and teachers, but also the voices of poets of distant eras. They also possessed a rare gift to distinguish the subtle voice of their "alter ego", reaching from the depths of the soul. Romantic ideas about the "alter", visible and invisible, real and phantom, will be categorically rejected by descendants as alien, dangerous and unacceptable ones. Being criticized, they will be tirelessly repeated until they are continued and developed in the psychoanalytic studies of K. Jung, the personalistic research of N. Berdyaev, the concept of "narcissistic mirages" by J. Lacan, the existentialism of A. Camus, the aesthetic theory of the absurd, philosophical and literary working of J. Deleuze and J. Baudrillard. However, it would be forgotten to allocate a place for them in the "genealogy of values", as, indeed, in the genealogy of the philosophy of illusion and simulacrum.

Without rejecting or obscuring the biological, creature (animal) component of human essence, the romantics of the 1820s were interested the least in a person as a social being, and if they were interested, then only in the Christian tradition - as a manifestation of the "dark" side of being, to which the "physiology" of both personality and society was attributed, as for both personality and society are subject to illness, decrepitude and death. In the romantic concept, man, a being both natural (as a divine creation) and social, is unhappy and doomed to loneliness. The search for "refuge" is more a philosophical and psychological than a social motive in romanticism. The German thinker F. Schlegel, the founder of romantic philosophy, sought refuge in "the highest skepticism", rejecting the possibility of cognition of "endless reality" and cyclical rotation, symbolized in the "miraculous image" of Wordsworth - "a rotating wheel with flashing spokes", likened to "the rapid change of day and night ", which De Quincey mentions while thinking about human passions, dubious and dangerous temptations to receive "keys of Paradise" (Quincey, 1994, p. 154) and resistance, which do not stop even for a moment, as a the "diurnal wheel with tirelessly flashing spokes does not stop its rotation" (Quincey, 2001, p. 154).

In the twentieth century knowledge of the XVIII - XIX centuries about the biophysiological norm and deviations from it, about physical diseases and mental disorders, was enriched by philosophical reflections on the "factors of the social environment", on spirituality and the mode of existence (Bandrovska, 2016). Anthropological ideas have defined and permanently consolidated the special worldview status of romanticism, its natural philosophy, historiography and fiction, as well as their specific lyric and philosophical discourse, in which all phenomena of nature, the earth and the universe are comprehended in the antonymic paradigm of life and death, eternity and moment, and at the same time they are filled with human meaning. The paradoxical nature of judgments clothed in metaphorical images complicates the perception of romantic ideologemes, mental and emotive characteristics of a person placed by romantics at the epicenter of 
a rapidly changing world, and therefore his activity, primarily reflective and sensual, deserves special attention.

\section{Purpose}

The purpose of the study is to show the connection of romanticism with its philosophy and anthropological doctrine that goes back to Hegelianism and Kantianism, and at the same time with the concepts of the future, structuralism and postmodernism.

\section{Methodology}

The study of the cultural diversity of romantic anthropologism requires a well-grounded integrated approach, understanding its influence as an epoch-making cultural and philosophical phenomenon and a "grand narrative" on the works of mythologists, philosophers, writers and poets of the late 19th and 20th centuries. The complex research includes various modern methods that are effective in the versatile study of romanticism as anthropological mythopoetics and mythopoeticism, later assimilated by European post-romantic and modernist literature. The complex methodological model allows to reveal more fully the stratagems of romantic thinking, to determine the features of mythopoetic reflection and anthropological approaches, the specifics of human vision and perception, imagination and creation of the romantic world-view. On the one hand, the reconstruction of archetypal symbolism, cultural and literary reminiscences in romantic mythmaking, presupposes the correlation of the ancient mythology, folklore genres and prototypes, on the other hand, the opposition, differentiation and analysis of the text requires abstract logical techniques and methods, derivatives from psychoanalytic research methodology, philosophy, myth criticism and culturology.

\section{Statement of basic materials}

Relying on the discoveries of the "German metaphysicians", the romantics went beyond these philosophers in the study of the human personality. In the mists of time, they looked for illustrations of their ideas in the myths and literature of antiquity, in medieval treatises and texts of Holy Scripture, in apocryphal publications, in the works of Plato and Neoplatonists. Armed with analysis and synthesis, the romantic authors compared myths, stories, parables, and philosophical fragments that served as illustrations of other people's and their own ideas about the "structure" of man, his place in the universe and society, as well as personal experiences colored with enthusiastic profundity and productive eclecticism. The first romantics who inherited the medieval mystics perceived man as an element of cosmic chaos, as a particle of this world (atom) in a pantheistic connection with natural elements (spirits) and universal energies (spirit): feelings and all natural properties of man were likened to natural manifestations, his social essence was outlined summarily, in an extended sense, and an abstract way.

Following I. Kant, Hegel, Fichte, Schelling, the English romantic T. de Quincey sought answers to the questions: what is a human? what is human thought? what does a human feel? what is feeling? what are its functions? what are visions and dreams, hallucinations and delusions? what is the difference between sleep and wakefulness? In the "Confessions of an English OpiumEater" the narrator De Quincey (1994), comprehending the Greek Stoics, finds for himself the definition of "Eclectic philosopher" (p. 157). French romantics, lyricizing philosophical discourse, asked themselves the questions: why does a person need imagination and reason, and 
which of them is more important for a human? What is the role of imagination in creativity? What is the difference between the imagination of the ancient man and the modern man? From the point of view of romantics, a human deserves compassion as being expelled from paradise and having lost divine protection, torn apart in toss between his divine, spiritual, and "dark", "demonic" essence. Left to himself, he finds himself in a tragic confrontation with external hostile forces, especially after the revolutionary upheavals in Europe at the end of the 18th century (Khmil \& Malivskyi, 2018). According to the poet W. Wordsworth, who showed a great interest in extreme psychological states, a human deserves compassion because he feels "guilt" and, like a beloved child of nature, yearns for his heavenly home (Wordsworth \& Coleridge, 2003, p. ix). Thomas De Quincey, a follower of Wordsworth, shows a young man, under the yoke of opposing forces, suffering from homelessness and mental discord, painfully aware of his "creaturehood", bringing him closer to natural beings gathering in flocks and herds.

The hero of A. de Lamartine, wishing to preserve the divine properties, seeks solitude for creativity, reflection, philosophy and poetry, inseparable in the mind of a romantic. Romantics consider philosophy, starting with the ancients, as poetry, and poetry as philosophy. However, opening new horizons of thinking, feeling for the connection between consciousness and the unconscious, reality and unreality, mythopoetics and rationalism, they still cannot give these parallels an accurate, objective definition. They are especially worried about the psychological aspect of this connection, the "sensitive bonds" between the outer and inner worlds, between thoughtfulness, the obvious divine nature, and self-immersion. Taking-the-inward-turn is a severe test of loneliness, predetermined from above, for a person is born also for love and for another being, similar to him and at the same time opposite to him. The gender essence of man was perceived by romantics not as the basis of biological and social consciousness, not as a social feeling, but as a religious and mystical feeling, for the progenitors of mankind, Adam and Eve, man and woman, were created by God for each other. In the romantic mind, feelings are spiritual, and eroticism is natural, for love bequeathed by God as a heavenly, blissful state.

The ideal of such a love for romantics was the union of Abelard and Eloise, Dante and Beatrice, Petrarch and Laura - "the unity of philosophy and Eros", "philosophical creativity" (Rozin, 2019, p. 126). "The Mystery of Love" is revived in a romantic elegy: You heard the vow and voice of my love / You often nourished the wanderer with thoughtfulness $<\ldots>$ (Batyushkov, 1977, p. 137). "Elegy" by K. Batyushkov, according to N. Fridman (1967), keeps the poet's addiction to "mathematically precise harmony of aesthetic forms" (p. 149). That is why mystical thought is devoid of "dark" depth, otherworldliness in it, speaking in the language of psychoanalysis, "inner Minotaur", with which a reflective person is destined to fight until the end of his days and overcome him or be overcome himself. The Elegy does not contain the triumph of the ego, characteristic of Western European literature of that time, striving to rise above the unhappy world, to become equal to the gods. There is also no individualistic isolation, selfish detachment from the world, oblivion in solitude, in the dreary realization that the rise and return home, to the "lotusland", is possible only in dreams, which was characteristic to Western romanticism of the same period.

Because, as J. Baudrillard (2000) wrote, "At the peak of value we are closest to ambivalence" (p. 47). Hence there is also the insistent need of Western man to know himself by "telling the soul", despising, condemning and "arrogantly sweeping aside" the "power of society" (Schreider, 2011). And with it - the gloomy materialism of a new civilization, oppressing the individual and pulling him into the "bottomless abyss" of the temptations of the big city, described in the "Con- 
fession" by T. De Quincey (1994, p. 114). De Quincey was one of the first authors to gain from personal experience the harsh laws of "political economy" of the new social order (Dyakonova, 2001, p. 7). De Quincey finds admirers and propagandists in France (Musset, Balzac, Gaultier, Baudelaire), in America (Poe, Hawthorne), in Russia (Gogol, Dostoevsky). The greedy image of London at night was compared by the English romantic to a dark "wolf's throat", for its darkness, in his words, is "beyond description" (Quincey, 1994, p. 114). In the novel of A. de Vigny (1987) romantic spirituality and exclusivity are opposed to the utilitarianism of faceless passersby crowding the Parisian streets - "strong red-faced men" who do not believe in "nervous diseases" (p. 260).

Here are the lines about London, drowning in natural and "man-made mists", in "yellow-gray puffs of clouds mixed with black coal smoke" (authors' transl.) (Vigny, 1987, p. 299). The tragic motive of industrialism prevailing over the personality will appear later in "The City of Terrible Night" by J. Thomson (1874). The continuation of romantic anthropic dualism and the apotheosis of nihilistic ideas, echoes of "bourgeoisophobia" and mistrust of reality, we find in the works of 20th century thinkers - in the arguments of philosophers and sociologists about the falsity of the visible present, about falsification of things and the manipulation of truth (Baudrillard, 2000). But this, however, does not prevent them from being tied to an object-oriented ontology through a system of symbolic exchange or, more precisely, thanks to the later one (King, 2019).

Romantics argued with the ideas of their predecessors and rethought them, supplemented and deliberately passed on to their descendants. This is one of the arguments in favour of the fact that the multifaceted nature of romanticism, its mythopoetics and symbolic discourse, the anthropological structure of images and texts must be studied in the context of its powerful, comprehensive, most often not declared by perceiving authors, impact on the subsequent world culture and scientific knowledge that has absorbed symbolism, modernism and postmodernism (Duarte, 2004). Many similar ideas, gleaned from the classicists and sentimentalists of the Enlightenment, were nevertheless subjected to revision. Making fun of the calculating efficiency of the "insensitive" bourgeois in Stello, A. de Vigny (1987) did not show himself as an opponent of Blaise Pascal, the founder of rationalism, since the ecstatic experience on the night of November 23-24, 1654, described by the author of "Memorial", evoked a deep sympathy. Pascal's description of religious feeling fitted well into the scheme of romantic anthropocentrism, into the concept of the duality of human nature. But the enlightenment knowledge about a man imperfect in his duality, once created in the image and likeness of the Almighty, has already been superimposed with romantic ideas about a rejected, lonely and suffering being.

Both the soul and the body of the romantics were considered as a kind of mechanism (machine), experiencing, on the one hand, the oppressive pressure of brains, on the other hand, the beneficial influence of a sublime poetic feeling. But the romantics could not yet foresee the consequences of the universal spread of duplicity, which became the subject of fundamental research by F. Nietzsche, S. Freud and C. Jung, J. Lacan, J. Deleuze and J. Baudrillard, who approached the problem from different angles. The "overthrower of Platonism" J. Deleuze will put forward the concepts of "criticism and clinic" and "spiritual cartography", defending the way of perceiving life, free from the influences of ideologies, religions and myths, which has recently attracted the attention of philologists (Charchare, 2017; Yurchuk, 2016). In the works of J. Deleuze and F. Guattari, the method of ramified cultural ties will take shape of the concept of identity-rhizome, which is the object of attention of modern writers (Putivtseva, 2019, p. 8). However, both this approach and the cognition of "simulacrum is truth" hide the illusion of ex- 
istence and demonstrate a play of imagination, reminiscent of the idealistic ideas of the era of romanticism about society and the man of the future. The postmodern thesis "simulacrum is truth", originating from the concept of duplicity, connects J. Baudrillard's (1981) reasoning about simulacrum and simulation models, about time and history as "the process of simulation" (p. 9).

There is a certain commonality of historical destinies in this. For these ideas Baudrillard, as once romantic authors for similar thoughts, was declared "the enemy of sound rational thinking" (Zenkin, 2000, p. 6). The considerations of J. Baudrillard about the system also has as its source in the ideas developed by predecessors and finally mastered the minds in a familiar form in the era of romanticism. "After all, the system is the mistress of everything: like the Lord God, it is free to bind and untie energies; impossible, and at the same time inevitable for it, is only one thing - reversibility" (authors' transl.) (Baudrillard, 2000, p. 48). This statement is reminiscent of the beginning of a philosophical dialogue in "Stello" (!), but the place of the "system" in it is occupied by "Destiny" (Vigny, 1987, p. 259). At first, the "vague", romantic image of the systemFate in the further narration is concretized - in the socio-political and lyrical-philosophical characteristics of history.

Vague is an important feature of a romantic symbol, necessary to express a changeable image-idea. Sonnet of G. de Nerval (1972) "El Desdichado" is an extremely vivid example of such a simulacrum, the disintegration of the "Ego" in a poetic illusion (p. 174).

The name "El Desdichado" ("Unhappy", "Deprived of inheritance"), refers to the motto of the knight Ivanhoe from the novel by W. Scott. But it is also an allusion to the free from connections, sinless "old Adam", and to the legacy of Orpheus, to which the lyrical "Ego" breaks through the eras, disintegrating into "pieces", reflected in fragments of time. Historical incarnations and mythopoetic metamorphoses of the "Ego", lofty feelings, the feeling of one's "plurality" spreading into infinity, of one's ecstatic presence in all known worlds and cultures, are locked on a single, whole, full-blooded symbol - the lyre of the mythical Orpheus. This image of "Ego" is demonstrative and illustrates the final alienation of the romantic with the enlightenment setting to delimit philosophy and poetry, myth and reality, declares the principle of blurring the boundaries between thought and sensitivity, thought and intuition.

In the opposition of types (Schreider, 2011) and in a kind of romantic hierarchy of heroes, in addition to the genius, but poor poet, a special, privileged place was taken by the famous yet impoverished philosopher, as well as the warrior, driver, leader. The historical leader was seen in various anthropological dimensions, acting either as a symbol of an ethnic group, country or civilization (Napoleon, Cromwell in the preface to "Cromwell" by W. Hugo); or as a misunderstood genius ("Moses" by A. de Vigny). Moses is an unselfish and lonely guide of people in his opposition to the imperfect world, a great leader endowed with a "jealous" God (Dieu jaloux), Almighty (Tout-Puissant) with enormous responsibility for the fate of a led people, by the end of a forty-year journey, is weary of his superhuman burden and unlimited power over people (Vigny, 1964, p. 39). And next to the great leaders always, according to the principle of contrast, an antipode appeared - the vain and ignorant, fussy and unlucky leader of the crowd (see the types of leaders in the story "Bug-Jargal" by V. Hugo) or a cruel usurper (M. Robespierre in the "History of one terror" by A. de Vigny). Refined, but boring aristocrats, who prefer balls, outfits and salon "chatter", were opposed by Liberty, leading to the barricades by E. Delacroix; the popular gypsy dancer Esmeralda in the novel "Notre-Dame de Paris" by V. Hugo; freedom-loving Carmen in the novella by P. Merimee; poor Indian woman in A. de Vigny's poem "The Wild Woman". Expressive female images among the French appeared under the influence of 
G. Byron (1974), his laconic, but vivid actors, lively characters - Medora and Gulnara from The Corsair, a brave Spanish woman who put her guitar aside and rushed into battle for the freedom of her country: "And, all unsexed, the anlace hath espoused, / Sung the loud song, and dared the deed of war?" (p. 164).

The contradictions and paradoxes of anthropological dimensions of romanticism, which made the nation dependent not only on the political and psychological atmosphere, historical and socio-cultural changes, but also on the geographic location, climate, and landscape of the country, were reflected in the outlining of ethnic differences, "local colour" and national characters. The same factors explained the state of the "mind" of the representatives of a particular nation, the peculiarities of the national mentality, "spirit" and character of the people. For Novalis, belonging to a nation prone to philosophical reflection (definition by A. de Lamartine), man appeared in organic forms and harmonics of the universe in the process of its formation and interaction with consciousness, as a property of a highly developed psyche. For Byron, the son of the "foggy Albion", man had a "rebellious mind". The Byron's Corsair, as the researcher writes, is "in the confusion of feelings", because he is drawn into the "abyss of chaos", "external and internal opposing passions caused by the relativity of the concepts of good and evil that was revealed to him" (authors' transl.) (Potnitseva, 2019, p. 12).

Byron endowed his characters with a part of his own experience, as A. Pushkin aptly noted, he gave them "one of the components" of his "strong and gloomy character". This is a very important observation of the epistemological and emotive nature of Byronism and romanticism in general, which calls for focusing attention on the creation of life. "The emphasis on experience is the epistemological foundation of romanticism", observes a modern scholar (Duarte, 2004). Let us add: first of all, on the psychic experience, which will be repeated and revived, revised, rethought, many decades later in crisis epochs - in the structuralist analysis of "narcissism" (J. Lacan), in "fundamental intuition" (R. Barthes), in the experience of the "inauthenticity of the world" (J. Baudrillard), given in a new cultural experience infected with "parasitic, secondary ideological meanings" (Zenkin, 2000, p. 7), in the modern experience of studying the dimensions of Plato's dialogues (Charchare, 2017).

The experience of the Corsair, revived, repeated by Byron in Lara, Giaur, Manfred, symbolized the state of mind of "a post-revolutionary man who found himself at the epicenter of the flow of good and evil" (authors' transl.) (Potnitseva, 2019, p. 12). Byronic accents are evident in the lyricism of A. de Lamartine - in a series of female deaths (série de deuils féminins), in the motif of the grave and the gloomy mourning of human fate (Arrous, 2019); in the dreamy and ironic criticism of the writer and journalist Ch. Nodier, in his rebellious, violently fantastic images (Dahan, 2019). But the Byronic sentiments are especially clearly visible in the poems of A. de Vigny (Zhuzhgina-Allahverdian, 2015). And yet, among the heroic personalities in French literature of this time, the poet is especially featured. It was he who was given the heroic mission of a disinterested people's driver and savior of peoples and was given to be the bearer of a mystical experience containing archetypal images that evoke a "feeling of transpersonal energy, a certain power that clearly exceeds the individual ego" (authors' transl.) (Zelensky, 1995, p. 291). The characters merge the archetypes of sacrifice - the mythical Orpheus and Prometheus, the biblical Moses.

The poet, born "under a lucky star", was given by the author the "star" name Stello (Vigny, 1987, p. 259) and the writer trusts him, as a descendant and heir of Homer and other great poets, to pronounce the Orphic "Poet's credo" (Vigny, 1987, p. 273). Under the influence of socio- 
utopian theories of the early 19th century (he was familiar with the followers of Saint-Simon Vigny and even attended their meetings) the image of the poet is transformed into a philosophical and poetic symbol of Light, Truth, Enlightenment in accordance with the "spirit" of the time, its religious and ethical principles. Realizing the power of the philosophy of skepticism, Vigny forces his characters "to choose between the method of Heraclitus and Democritus", that is, between misanthropy, gloomy pessimism, and bliss, a calm state of mind, independent of external benefits. The black doctor, this "inveterate skeptic", says to the sensitive Stello: "To shed tears over life is to value it truly too highly; only saddens and accusers take it too close to heart. <...> You should be much less worried when watching a boring spectacle, which is a human race, incapable of either good or evil" (authors' transl.) (Vigny, 1987, p. 306).

In their concept of Orphism and Prometheism, the romantics relied not so much on ancient myths as on the teachings of Plotinus and Proclus, as well as the later Christian thinker, Origen. In their writings, a source was found that nourished romantic utopianism, the doctrine of stellar birth and numinous beauty, an educating mission and brilliant insights that were developed in theosophy of the mid-19th century. However, the apogee of sacrifice among romantics is the mystery of Christ.

According to A. Besant (1991), the movement towards mystery (of the soul), "a return to its spiritual form", is necessary in order to avoid the "circle of births and abundant wanderings", "to reach true Being", like the mystics of Bacchus and Proserpine, initiated by Orpheus, who their "cathartic virtues" achieved "godlikeness", union with the deity through the "beatific Ego within oneself". At the same time, Besant referred to Vigny his "Moses". However, Vigny’s biblical Moses, the ideological forerunner of Christ, the messiah, the driver and the prophet, is endowed with a romantic soul: he suffers from loneliness and misunderstanding, "inner dichotomy and doubleness" in the Schlegelian tradition. Romantic allegory, metaphor, metonymy - this is the mental code of the romantic Truth, amenable to awareness through the aesthetic idea that permeates the narrative, text, images.

Romantics made the method of metaphorical parallelism universal, applying it to philosophy and natural science (natural philosophy), sociology, metaphysics and "human knowledge" (Zhuzhgina-Allahverdian, 2015, p. 6). In romantic text, there were a metaphorizing of thaught about a person and a lyricizing of anthropological discourse, as a necessary and inevitable stage in the human knowledge, which combined the mythopoetic methodology with analysis of collective ideas about the individual and the world around him, its external and behavioral atypicality, egocentric isolation and individualistic marginality, a person beyond general standards and stereotypes and actualized the principle of binarism (Bandrovska, 2016). In the 1830s Romantics realized that the deep essence of a person is representations that reflect not only the inner world and universal events, but also social being, which cannot be ignored, since it significantly affects the "events" of inner life, the spiritual content of a person and his psychophysical nature. The discovery of a new personality trait motivated the desire to discover the integrity, the unity of the physical and mental-spiritual in a person, voluntarily or involuntarily drawn into social life, and required deep analysis and proof, in contrast to the Christian idea on the duality of human nature.

\section{Originality}

The originality of our research is in the study of the features of romanticism of the 18201830 -ies as a humanistic discourse about the paradoxes of romantic consciousness that underlie the emerging liberal philanthropy and philosophical nihilism. The central figure in this discourse 
is the reflective person, represented, on the one hand, in his "duality", in the struggle with himself, on the other, in the diversity of relations with the world. The romantic dimensions of individualism and egocentrism, doubting reason and broken faith became the root from which theories about personality and its relationship to the social order and the divine universe, personalism, psychoanalysis, the philosophy of the "other" and postmodernist theories about illusion, simulacrum, rhizome, and binarism.

The guesses, assumptions and predictions of romantic authors, their vision of man's relationship with the world, God, nature and society, based on contemporary scientific knowledge about a man as a physical, intellectual, mental and spiritual being, about his mission and social purpose, will be actualized and justified in the teachings of the twentieth century.

\section{Conclusions}

The romantic ideas about man, about progressive evolution and the cycling development were not new, but were reconstructed and reworked in the scientific context of the era in their opposition and simultaneous connection with the old views and illusions about the human world. These features are decisive in substantiating the concept of "romantic human study" and its methodology, interdisciplinary approaches to the romantic personality study of 1820-1830s. Thanks to the depth of analytical thought, multifaceted by metaphorical imagery and aphoristic accuracy of statements about people, deep penetration into the study of historical parallels and the evolutionary fate of mankind, versatility and wealth of research talent of the romantic authors, many philosophical thoughts and provisions have remained relevant to this day and not only contradict modern anthropology, but in many respects coincide with it.

\section{REFERENCES}

Arrous, M. (2019). Lamartine ou la vie lyrique, A. Foglia et L. Zimmermann. Studi Francesi, (188 (LXIII | II)), 368-369. DOI: https://doi.org/10.4000/studifrancesi.19931 (in French)

Bandrovska, O. T. (2016). Identychnist Inshoho v anhliiskomu modernistskomu romani: Tilo poza normoiu kriz mizhdystsyplinarni pidkhody. From Baroque to Postmodernism: A Journal of literary Studies, 20, 134-140. (in Ukrainian)

Batyushkov, K. N. (1977). Stikhotvoreniya. Moscow: Khudozhestvennaya literatura. (in Russian)

Baudrillard, J. (1981). Simulacres et simulation. Galilee. (in French)

Baudrillard, J. (2000). Simvolicheskiy obmen i smert. Moscow: Dobrosvet. (in Russian)

Besant, A. (1991). Ezotericheskoe khristianstvo, ili Malye misterii. Moscow: ART+N. (in Russian)

Byron, G. G. (1974). Palomnichestvo Chayld Garolda. In Sochineniya (Vol. 1, pp. 141-297). Moscow: Khudozhestvennaya literatura. (in Russian)

Charchare, H. (2017). Proust et Platon. Convergences linguistiques, érotiques et philosophiques. Université Sorbonne Paris Cité. (in French)

Dahan, J. R. (2019). Compte rendu des Cahiers d’études nodiéristes, 2017-2, № 4 : "Charles Nodier et la presse de son temps". Revue d'histoire littéraire de la France. Retrieved from http://srhlf.free.fr/PDF/ Charles_Nodier_et_la_presse_de_son_temps.pdf (in French)

Duarte, L. F. D. (2004). The romantic drive and human sciences in the western culture (La pulsion romantique et les sciences humaines en occident). Revista Brasileira de Ciências Sociais, 19(55), 5-18. DOI: https://doi.org/ 10.1590/s0102-69092004000200001 (in English)

Dyakonova, N. Y. (2001). Tomas de Quincey - povestvovatel. In Confession of an English Opium-Eater (pp. 5-24). St. Petersburg: Azbuka. (in Russian)

Foucault, M. (2015). O "Dialogakh" Russo. In N. T. Pakhsaryan (Ed.), Michel Foucault i literatura (pp. 7-27). St. Petersburg: Aleteya. (In Russian)

Fridman, N. V. (1967). Batyushkov i romanticheskoe dvizhenie. In Problemy romantizma (pp. 92-153). Moscow. (in Russian) 
Khmil, V., \& Malivskyi, A. (2018). The Problem of Forms of Completing the Copernicus Revolution in Modern Cartesian Science. Philosophy and Cosmology, 21, 131-139. DOI: https://doi.org/10.29202/phil-cosm/21/14 (in English)

King, M. J. (2019). Object-Oriented Baudrillard? Withdrawal and Symbolic Exchange. Open Philosophy, 2(1), 75-85. DOI: https://doi.org/10.1515/opphil-2019-0008 (in English)

Nerval, G. de. (1972). Aurélia. Les Chimères. La Pandora. Paris: Le Livre de Poche. (in French)

Potnitseva, T. N. (2019). Angliyskie romantiki i russkie miratores ("Korsar" Bayrona v interpretatsii V. Olina). In Izbrannye istorii iz istorii literatury (pp. 11-22). Dnepr: DNU. (In Russian)

Putivtseva, N. K. (2019). Problematyka martynikanskoi ta antylskoi samobutnosti u tvorchosti Eduara Hlissana. (Avtoreferat dysertatsii kandydata filolohichnykh nauk). Petro Mohyla Black Sea National University, Mykolaiv. (in Ukrainian)

Quincey, T. de. (1994). Confessions of an English Opium-Eater. Wordsworth Editions Limited. (in English)

Quincey, T. de. (2001). Confession of an English Opium-Eater. St. Petersburg: Azbuka. (in Russian)

Rozin, V. M. (2019). Not only about Love: About Philosophers, their Lovers and Time (Reflections on the Book "Philosophical Emanations of Love"). History of Philosophy, 24(2), 126-135. DOI: https://doi.org/ 10.21146/2074-5869-2019-24-2-126-135 (in Russian)

Schlegel, F. (1983). Estetika. Filosofiya. Kritika (Vol. 2). Moscow: Iskusstvo. (in Russian)

Schreider, N. S. (2011). Iz istoriko-literaturnogo naslediya. Dnepropetrovsk: ART-PRESS. (in Russian)

Shervashidze, V. V. (2016). Drama "literaturnogo soznaniya": Ot romantizma k postmodernizmu. In Literatura i ideologiya: Vek dvadtsatyy (pp. 365-371). MAKS Press. (in Russian)

Vigny, A. de. (1964). Oeuvres complètes. Paris: Seuil. (in French)

Vigny, A. de. (1987). Izbrannoe. Moscow: Iskusstvo. (in Russian)

Wordsworth, W., \& Coleridge, S. T. (2003). Lyrical Ballads and Other Poems. Wordsworth Editions Limited. (in English)

Yurchuk, O. O. (2016). Heohrafichne myslennia v khudozhnii literaturi. Kontaktni zony v antropolohii i teorii literatury. Khudozhni fenomeny $v$ istorii svitovoi literatury: Perekhid movy v pysmennytstvo ("Horyzont ochikuvannia"): Tezy dopovidei II mizhnarodnoi naukovoi konferentsii, April 8-9, 2016, Kharkiv, 99. (in Ukrainian)

Zelensky, V. (1995). Posleslovie. In C. G. Jung, Analiticheskaya psikhologiya: Proshloe i nastoyashchee (p. 291). Moscow. (In Russian)

Zenkin, S. (2000). Jean Baudrillard: Vremya simulyakrov. In J. Baudrillard, Simvolicheskiy obmen i smert (pp. 5-40). Moscow: Dobrosvet. (in Russian)

Zhuzhgina-Allahverdian, T. N. (2015). Frantsuzskaya romanticheskaya literatura 1820-kh gg.: Struktura mifopoeticheskogo teksta: Monografiya. Dnepropetrovsk, NGU. (in Russian)

\section{LIST OF REFERENCE LINKS}

Arrous M. Lamartine ou la vie lyrique, A. Foglia et L. Zimmermann. Studi Francesi. 2019. Iss. 188 (LXIII | II). P. 368-369. DOI: https://doi.org/10.4000/studifrancesi.19931

Бандровська О. Т. Ідентичність Іншого в англійському модерністському романі: тіло поза нормою крізь міждисциплінарні підходи. Від бароко до постмодернізму. 2016. Вип. 20. С. 134-140.

Батюшков К. Н. Стихотворения. Москва : Худож. лит., 1977. 206 с.

Baudrillard J. Simulacres et simulation. Galilee, 1981. 240 p.

Бодрийяр Ж. Ж. Символический обмен и смерть. Москва : Добросвет, 2000. 387 с.

Безант А. Эзотерическое христианство, или Малье мистерии. Москва : АРТ+N, 1991. 195 с.

Байрон Д. Г. Паломничество Чайльд Гарольда. Сочинения : в 3 т. Москва : Худож. лит., 1974. Т. 1. С. $141-297$.

Charchare H. Proust et Platon. Convergences linguistiques, érotiques et philosophiques. Université Sorbonne Paris Cité, 2017. 576 p.

Dahan J. R. Compte rendu des Cahiers d’études nodiéristes, 2017-2, № 4 : "Charles Nodier et la presse de son temps". Revue d'histoire littéraire de la France, 2019. URL: http://srhlf.free.fr/PDF/ Charles_Nodier_et_la_presse_de_son_temps.pdf

Duarte L. F. D. The romantic drive and human sciences in western culture (La pulsion romantique et les sciences humaines en occident). Revista Brasileira de Ciências Sociais. 2004. Vol. 19. Iss. 55. P. 5-18. DOI: https://doi.org/10.1590/s0102-69092004000200001 
Дьяконова Н. Я. Томас де Квинси - повествователь. Исповедь англичанина, употреблявщего опиум / Т. де. Квинси. Санкт-Петербург : Азбука, 2001. С. 5-24.

Фуко М. О "Диалогах" Руссо. Мишель Фуко и литература / под ред. Н. Т. Пахсарьян. Санкт-Петербург : Алетейя, 2015. С. 7-27.

Фридман Н. В. Батюшков и романтическое движение. Проблемы романтизма. Москва, 1967. С. 92-153.

Khmil V., Malivskyi A. The Problem of Forms of Completing the Copernicus Revolution in Modern Cartesian Science. Philosophy and Cosmology. 2018. Vol. 21. P. 131-139. DOI: https://doi.org/10.29202/phil$\operatorname{cosm} / 21 / 14$

King M. J. Objekt-Oriented Baudrillard? Withdrawal and Symbolic Exchange. Open Philosophy. 2019. Vol. 2. Iss. 1. P. 75-85. DOI: https://doi.org/10.1515/opphil-2019-0008

De Nerval G. Aurelia. Les Chimères. La Pandora. Paris : Le Livre de Poche, 1972. 268 p.

Потницева Т. Н. Английские романтики и русские miratores ("Корсар" Байрона в интерпретации В. Олина). Избранные истории из истории литературы. Днепр : ДНУ, 2019. С. 11-22.

Путівцева Н. К. Проблематика мартиніканської та антильської самобутності у творчості Едуара Гліссана : автореф. дис. ... канд. філол. наук. Чорномор. нац. ун-т ім. Петра Могили. Миколаїв, 2019. 20 с.

De Quincey T. Confessions of an English Opium-Eater. Wordsworth Editions Limited, 1994. 312 p.

Де Квинси Т. Исповедь англичанина, употреблявщего опиум. Санкт-Петербург : Азбука, 2001. 224 с.

Розин В. М. Не только о любви: о философах, их возлюбленных и времени (Размышления по поводу книги "Философские эманации любви"). История философии. 2019. Т. 24. № 2. С. 126-135. DOI: https://doi.org/10.21146/2074-5869-2019-24-2-126-135

Шлегель Ф. Эстетика. Философия. Критика : в 2 т. Москва : Искусство, 1983. Т. 2. 448 с.

Шрейдер Н. С. Из историко-литературного наследия. Днепропетровск : АРТ-ПРЕСС, 2011. 418 с.

Шервашидзе В. В. Драма "литературного сознания": от романтизма к постмодернизму. Литература и идеология. Век двадиатый. МАКС Пресс, 2016. С. 365-371.

De Vigny A. Oeuvres complètes. Paris : Seuil, 1964. 661 p.

Де Виньи А. Избранное. Москва : Искусство, 1987. 606 с.

Wordsworth W., Coleridge S. T. Lyrical Ballads and Other Poems. Wordsworth Editions Limited, 2003.210 p.

Юрчук О. О. Географічне мислення в художній літературі. Контактні зони в антропології і теорії літератури. Художні феномени в історії світової літератури: перехід мови в письменництво ("Горизонт очікування"). Тези доповідей II міжнар. наук. конф. (Харків, 8-9 квітня 2016 р.). Харківський національний університет імені В. Н. Каразіна. Харків, 2016. С. 99.

Зеленский В. Послесловие. Аналитическая психология: Прошлое и настоящее / К. Г. Юнг. Москва, 1995. C. 291.

Зенкин С. Жан Бодрийяр: время симулякров. Символический обмен и смерть / Ж. Бодрийяр. Москва : Добросвет, 2000. С. 5-40.

Жужгина-Аллахвердян Т. Н. Франиузская романтическая литература 1820-х г2.: структура мифопоэтического текста : монография. Днепропетровск : НГУ, 2015. 280 с.

\section{Т. Н. ЖУЖГІНА-АЛЛАХВЕРДЯН ${ }^{1 *}$, С. А. ОСТАПЕНКО ${ }^{2 *}$}

\footnotetext{
${ }^{1 *}$ Горлівський інститут іноземних мов Державного вищого навчального закладу "Донбаський державний педагогічний університет" (Бахмут, Україна), ел. пошта allakverdian.tamara@rambler.ru, ORCID 0000-0002-5953-4424

2* Донецький національний університет економіки і торгівлі імені Михайла Туган-Барановського (Кривий Ріг, Україна), ел. пошта ostapenko@donnuet.edu.ua, ORCID 0000-0002-3915-4854
}

\section{РОМАНТИЗМ ЯК ЛЮДИНОЗНАВСТВО: ОСОБЛИВОСТІ ФІЛОСОФІЇ ОСОБИСТОСТІ (НА МАТЕРІАЛІ ЕВРОПЕЙСЬКОЇ ЛІТЕРАТУРИ 1820-1830-Х РР.)}

Мета дослідження - показати зв'язок романтизму з антропологічним вченням, що сходить до гегельянства та кантіанства, і водночас - 3 концепціями майбутнього, структуралізмом і постмодернізмом. Теоретичний базис. Оскільки проблема людини - центральна у романтизмі, остільки є сенс окремо виділити в антропологічній науці "романтичне людинознавство" як історичну віху в ученні про людину конкретного історико- 
культурного періоду, відомого у науковій літературі під назвою "епоха романтизму". Художня література цього часу, що тісно пов'язана з філософією і науковим знанням, доводить глибину і актуальність аналітичної думки про людину бінарних станів, вираженої за допомогою багатогранної метафоричної образності й афористично точних висловлювань, які демонструють різнобічність теоретичного і практичного людинознавства. Наукова новизна. Особливості романтичного світогляду 1820-1830-х рр. визначили специфіку романтичного художнього і людинознавчого дискурсу, його суперечностей і парадоксів; а також романтичної думки, що тяжіє до символу і символізму, - одночасно логічною і алогічною, повної ліберального людинолюбства і наділеної песимізмом. Широта матеріалу, який приєднали романтики з історії, філософії, міфології, літератури та мистецтв, необмеженість дослідницьких інтересів, помножених на творчу наснагу і уяву, визначили стрибкоподібне мислення і фрагментарність образу людини. Рефлектуюча людина представлена романтиками не тільки у своїй "подвійності" і в боротьбі із самим собою, але також у різноманітті відносин зі світом, що дозволяє нам назвати цю область думки "романтичним людинознавством", яке вимагає міждисциплінарних підходів дослідження. Основні ідеї романтиків про людину як суперечливу особистість, романтичні вимірювання індивідуалізму та егоцентризму, "бурхливої душі" і "бунтівного розуму" в епоху "порушеної віри", стали тим коренем, з якого розвинулися психоаналіз та аналітична психологія, філософія "іншого" та постмодерністське вчення про міфи, концепції ілюзії та симулякра, бінаризму та ін. Висновки. Структурний аналіз численних художніх та естетичних текстів епохи романтизму показує, що письменники першої половини XIX століття надавали романтичній думці й образам антропологічного смислу та, по суті, заклали основи сучасного "людинознавства" і "суспільствознавства", створили базис для історичної, соціальної, психологічної, культурологічної та психоаналітичної антропології.

Ключові слова: романтизм; людина; людинознавство; філософія особистості; філософія "іншого"; особистісні мотиви; індивідуалізм; авторський міф; бінарність; симулякр

\section{Т. Н. ЖУЖГИНА-АЛЛАХВЕРДЯН ${ }^{1^{*}}$, С. А. ОСТАПЕНКО ${ }^{2 *}$}

\footnotetext{
${ }^{1 *}$ Горловский институт иностранных языков Государственного высшего учебного заведения

"Донбасский государственный педагогический университет" (Бахмут, Украина), эл. почта allakverdian.tamara@rambler.ru, ORCID 0000-0002-5953-4424

2* Донецкий национальный университет экономики и торговли имени Михаила Туган-Барановского (Кривой Рог, Украина), эл. почта ostapenko@donnuet.edu.ua, ORCID 0000-0002-3915-4854
}

\section{РОМАНТИЗМ КАК ЧЕЛОВЕКОЗНАНИЕ: ОСОБЕННОСТИ ФИЛОСОФИИ ЛИЧНОСТИ (НА МАТЕРИАЛЕ ЗАПАДНОЕВРОПЕЙСКОЙ ЛИТЕРАТУРЫ 1820-1830-Х ГГ.)}

Цель исследования - показать связь романтизма с антропологическим учением, восходящим к гегельянству и кантианству, и одновременно - с концепциями будущего, структурализмом и постмодернизмом. Теоретический базис. Поскольку проблема человека - центральная в романтизме, постольку есть смысл отдельно выделить в антропологической науке "романтическое человекознание" как историческую веху в учении о человеке конкретного историко-культурного периода, известного в научной литературе под названием "эпоха романтизма". Художественная литература этого времени, тесно связанная с философией и научным знанием, доказывает глубину и актуальность аналитической мысли о человеке бинарных состояниях, выраженной с помощью многогранной метафорической образности и афористически точных высказываний, демонстрирующих разносторонность теоретического и практического человекознания. Научная новизна. Особенности романтического мировоззрения 1820-1830-х гг. определили специфику романтического художественного и человековедческого дискурса, его противоречий и парадоксов; а также романтической мысли, тяготеющей к символу и символизму, - одновременно логичной и алогичной, исполненной либерального человеколюбия и окрашенной пессимизмом. Широта приобщенного романтиками материала - по истории, философии, мифологии, литературе и искусствам, неограниченность исследовательских интересов, помноженных на творческое воодушевление и воображение, определили скачкообразность мышления и фрагментарность образа человека. Рефлектирующий человек представлен романтиками не только в его "двойственности" и в борьбе с самим собой, но также во многообразии отношений с миром, что позволяет нам назвать эту область мысли "романтическим человекознанием", требующим междисциплинарных подходов исследо- 
вания. Основные идеи романтиков о человеке как противоречивой личности, романтические измерения индивидуализма и эгоцентризма, "смятенной души" и "мятежного разума" в эпоху "поколебленной веры", стали тем корнем, из которого развились психоанализ и аналитическая психология, философия "другого" и постмодернистское учение о мифе, концепции иллюзии и симулякра, бинаризме и др. Выводы. Структурный анализ многочисленных художественных и эстетических текстов эпохи романтизма показывает, что писатели первой половины XIX века придавали романтической мысли и образам антропологический смысл и, по сути, заложили основы современного "человековедения" и "обществоведения", создали базис для исторической, социальной, психологической, культурологической и психоаналитической антропологии.

Ключевые слова: романтизм; человек; человекознание; философия личности; философия "другого"; личностные мотивы; индивидуализм; авторский миф; бинарность; симулякр

Received: 03.05.2020

Accepted: 19.11.2020 